\title{
Bioecology of Cletus capitulatus Fabricius (Hemiptera: Coreidae) on Fameflower Talinum paniculatum Jacq. (Gaertn)
}

\author{
Rismayani $^{1, *}$, and Rohimatun ${ }^{1}$
}

\author{
${ }^{1}$ Indonesian Spice and Medicinal Crops Research Institute (ISMCRI) \\ Tentara Pelajar Street, Number 3, Cimanggu, Bogor, West Java, Indonesia \\ *e-mail: rismayani.queen@gmail.com
}

\begin{abstract}
S
One of the local medicinal plant resources widely used for medicine is a fameflower Talinum paniculatum Jacq. (Gaertn.). This plant is mostly used for energy drink or tonic to stimulate performance. Coried bug, Cletus capitulatus (Hemiptera: Coreidae), was found attacking $T$. paniculatum plant in the medicinal plant science techno park, Bogor. This pest destroys the plant by piercing the fruit and sucking the liquid inside the fruit, consequently the healthy and reddish fruit will be dry and browning like burned and eventually falls out. No previous reports on this pest attack on this plant. The aim of this study is to investigate the bioecology of C. capitulatus, particularly on fameflower. This information will be beneficial for the development of control strategies and for rearing the insects to support the further research activities. The study was conducted at the pest laboratory of Indonesian Spice and Medicinal Crops Research Institute (ISMCRI) from November 2016 to Mei 2017. Bioecological of C. capitulatus was observed, and data were recorded by digital MicroCapture Pro Ver 2.3 from egg to adult every 24 hours. The longevity and size of body both male and female were measured. The result shows that the development time of $C$. capitulatus male and female from egg to adult were 14,8 $\pm 0,30$ and 27,7 $\pm 0,48$ days respectively, which were through the egg phase, instar nymphs $1,2,3,4,5$ and adult. Female showed to develop longer than the male.
\end{abstract}

Keywords: bioecology, Cletus capitulatus, fameflower, medicinal plant

\section{INTRODUCTION}

Indonesia is a tropical country which is located in the equator region between $06^{\circ} 04^{\prime} 30^{\prime \prime}$ north latitude - 1100 '36" south latitude, making Indonesia has great potential as a country which has a wealth of natural resources and abundant genetic diversity. One of the natural resources used as a raw material for medicine and vegetables, and has the potential to be developed is the fameflower (Talinum paniculatum Jacq. (Gaertn.)) (Talinaceae). Fameflower is a native plant in the Southern United States. This plant firstly introduced to Indonesia at Bogor Botanical Garden in 1915 from Suriname. The species of fameflower widely cultivated in Indonesia are T. triangulare (Jacq.) Willd and $T$. paniculatum [1]. Fameflower can be grown in the garden or in the pot, because this plant is easy to be propagated and grow fast [2].

Almost all the parts of fameflower can be used. It is mostly used as a tonic and an energy drink (aphrodisiac) [3], and as a substitute of ginseng (Panax ginseng CA Meyer (Araliaceae)). The leaf can be used as a vegetable. Fameflower's leaf is one of the antioxidants resources containing fiber, flavonoids, saponins, alkaloids, tannins, and other compounds which can improve blood circulation, provitamin A, and various important minerals [4].
One of the problems for cultivating the fameflower is the attack of fruit sucker coreid bug Cletus capitulatus (Herrich-Schäffer) (Hemiptera: Coreidae). This particular pest is found in fameflower plantation in Bogor. Cletus sp. is a polyphagic, not only attacking fameflower, but also spinach, ricefield and soybean [5]; [6]; [7]; [8]. Adult and nymph of $C$. capitulatus destroy fameflower's fruit by pricking and sucking the liquid inside the fruit. Thus, the fresh and reddish fruit suddenly turns to brown or black colour as it burns, dries and falls out. To our knowledge, this is the first study evaluating the bioecology of $C$. capitulatus attacking fameflower in Indonsian. The understanding on the insect bioecology is very important as a basic step for rearing the insect for research and as the first information to support the Integrated Pest Management (IPM) in fameflower cultivation. This study aims to understand the bioecology of $C$. capitulatus (Hemiptera: Coreidae) on fameflower.

\section{MATERIALS AND METHODS}

\subsection{Time and Place of Study}

The study was conducted at the pest laboratory, Indonesian Spice and Medicinal Crops Research 
Institute (ISMCRI), Bogor, from November 2016 to May 2017.

\subsection{Insect Collecting and Rearing}

Cletus capitulatus was collected from fameflower plant with a sweep net. Insect rearing was conducted in a laboratory with temperature of 25-28 ${ }^{\circ} \mathrm{C}$. Nymph and adult were reared in plastic box (length $30 \mathrm{~cm}$, width $24 \mathrm{~cm}$, and height $20 \mathrm{~cm}$ ). Nymph and adult were fed with fameflower's fruit every day or two days.

\subsection{Developmental Observation}

The mated adult female of $C$. capitulatus was put in the cage box (length $30 \mathrm{~cm}$, width $24 \mathrm{~cm}$, and height $20 \mathrm{~cm}$ ) containing fameflower plant as a food resource and host. This was repeated 20 times. The adult female was left around 24 hours for laying the egg inside the cage box. After 24 hours, the adult female was returned into a rearing box, and one egg laid by female was left to develop until adult. If the female produced more than one egg in 24 hours, the other eggs were removed by brush, and only one egg was left in a cage box to be observed. Every 24 hours, the egg developmental phase until adult was observed. The length and width of C. capitulatus in each developmental stage were calculated with measuring paper $(\mathrm{mm})$ and calibrated ruler under digital microscope MicroCapture Pro Ver 2,3. The longevity of each stadium from egg to adult also were recorded. Data obtained were analyzed using t-test in Microsoft excel to evaluate the difference of each parameter.

\section{RESULTS AND DISCUSSION}

\subsection{Biology and Description of C. capitulatus} Fabricius

Cletus capitulatus has a paurometabola metamorphosis from egg-nymph-adult. The egg is yellowish-white, with the elips shape length around 1,4 $-1,7 \mathrm{~mm}$. Female lays eggs on the flower stem and the fruit. During its life, the female can produce eggs around 10 to 15 eggs. The body size of female bigger than the male (Figure 1h). The average length and width of the female abdomen was $8,72 \mathrm{~mm}$ and 8,82 $\mathrm{mm}$, respectively. While, the average length and width of the male abdomen was $8,55 \mathrm{~mm}$ and $7,97 \mathrm{~mm}$, respectively (Table 1 ).

The $1^{\text {st }}$ instar nymph is green transparent, and soft, so the inside of the body can be seen clearly. There is dark part in the middle of the abdomen, and visible blood vessels are on the right and left sides of the abdomen (Figure 1b). The body characteristics of the $2^{\text {nd }}$ and $3^{\text {rd }}$ instar nymphs are similar the $1^{\text {st }}$ instar nymph, which is transparent green, and soft, the difference is on its size. The blood vessels are not visible due to the dark body, and the thorax changes to black (Figures 1c and d).

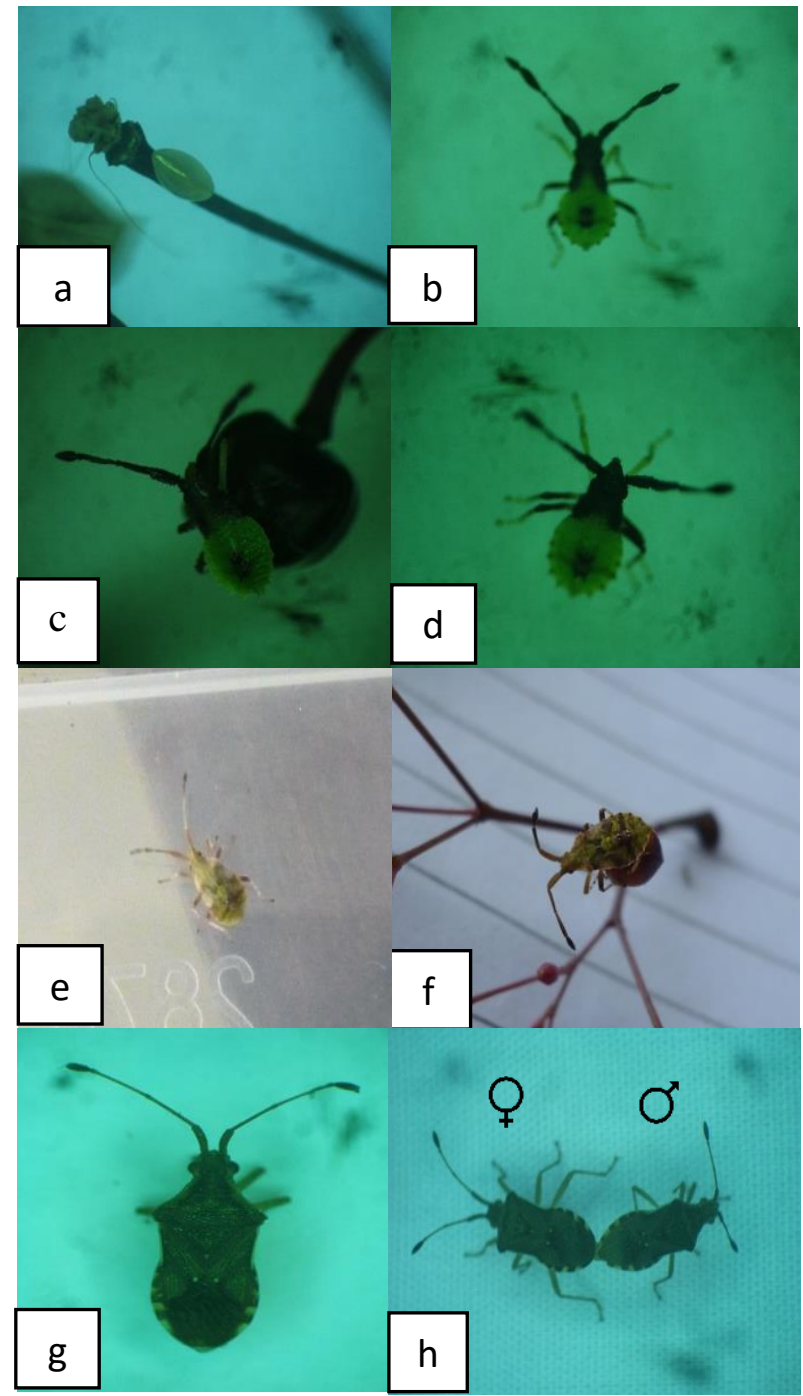

Figure 1. Life cycle of $C$. capitulatus Fabricius; a. Egg; b. $1^{\text {st }}$ instar nymph; c. $2^{\text {nd }}$ instar nymph; $d$. $3^{\text {rd }}$ instar nymph; e. $4^{\text {th }}$ instar nymph; f. $5^{\text {th }}$ instar nymph; g. Adult; h. Male and female adults were mating.

In the $4^{\text {th }}$ and $5^{\text {th }}$ instars nymph phases look different compared to the previous instar nymphs. The body hardened and the color was no longer transparent green. Therefore, the inside part of the body could not be clearly seen. The $5^{\text {th }}$ instar nymphs are slightly different than the $4^{\text {th }}$ instar nymph, and the greenish color has started to turn into brown (Figure 1f).

The body texture on the adult phase of $C$. capitulatus hardened. The color of all parts of the body changed to light brown with black stripes all over its sides and in some parts of the abdomen and thorax. The abdomen of the adult female is black, while the adult male has brown abdomen like all of the body parts. The back of the male abdomen is more tapered compared to that on female abdomen (Figure 1h). 
Table 1 The average of body size of male and female $C$. capitulatus in all developmental stages

\begin{tabular}{|c|c|c|c|c|c|c|c|c|}
\hline \multirow{2}{*}{\multicolumn{3}{|c|}{ Part of the body }} & \multicolumn{6}{|c|}{ Body size average $(\mathrm{mm})$} \\
\hline & & & \multirow{2}{*}{$\begin{array}{c}\begin{array}{c}\mathbf{1}^{\text {st }} \\
\text { instar } \\
\text { nymph }\end{array} \\
0,77 \mathrm{a}\end{array}$} & \multirow{2}{*}{$\begin{array}{c}\begin{array}{c}2^{\text {nd }} \\
\text { instar } \\
\text { nymph }\end{array} \\
0,90 \mathrm{a}\end{array}$} & \multirow{2}{*}{$\begin{array}{c}\begin{array}{c}\mathbf{3}^{\text {rd }} \\
\text { instar } \\
\text { nymph }\end{array} \\
3,11 \mathrm{a}\end{array}$} & \multirow{2}{*}{$\begin{array}{c}\begin{array}{c}4^{\text {th }} \\
\text { instar } \\
\text { nymph }\end{array} \\
4,31 \mathrm{a}\end{array}$} & \multirow{2}{*}{$\begin{array}{c}\mathbf{5}^{\text {th }} \\
\text { instar } \\
\text { nymph }\end{array}$} & \multirow{2}{*}{$\begin{array}{c}\text { Adult/Image } \\
4,31 \mathrm{a}\end{array}$} \\
\hline Head & \multirow[t]{2}{*}{ Length } & $\sigma$ & & & & & & \\
\hline & & Q & $0.93 \mathrm{~b}$ & $0,99 \mathrm{~b}$ & $3,20 \mathrm{~b}$ & $3,97 \mathrm{~b}$ & $3,96 \mathrm{~b}$ & $3,97 \mathrm{~b}$ \\
\hline & \multirow[t]{2}{*}{ Width } & $\sigma$ & $0,81 \mathrm{a}$ & $0,90 \mathrm{a}$ & $2,66 \mathrm{a}$ & $3,42 \mathrm{a}$ & $3,42 \mathrm{a}$ & $3,42 \mathrm{a}$ \\
\hline & & Q & $0,98 \mathrm{~b}$ & $0,82 \mathrm{~b}$ & $2,71 \mathrm{~b}$ & $3,47 \mathrm{~b}$ & $3,47 \mathrm{~b}$ & $3,47 \mathrm{~b}$ \\
\hline \multirow[t]{4}{*}{ Thorax } & \multirow[t]{2}{*}{ Length } & $\sigma^{\prime \prime}$ & $0,63 \mathrm{a}$ & $0,94 \mathrm{a}$ & $2,79 \mathrm{a}$ & $3,90 \mathrm{a}$ & $3,90 \mathrm{a}$ & $3,90 \mathrm{a}$ \\
\hline & & Q & $0,84 \mathrm{~b}$ & $0,70 \mathrm{~b}$ & $2,53 \mathrm{~b}$ & $4,09 \mathrm{~b}$ & $4,09 \mathrm{~b}$ & $4,09 \mathrm{~b}$ \\
\hline & \multirow[t]{2}{*}{ Width } & $\sigma^{\prime}$ & $1,19 \mathrm{a}$ & $1,23 \mathrm{a}$ & $3,94 \mathrm{a}$ & $6,16 \mathrm{a}$ & $6,16 \mathrm{a}$ & $6,16 \mathrm{a}$ \\
\hline & & Q & $1,42 \mathrm{~b}$ & $1,29 \mathrm{~b}$ & $4,05 \mathrm{~b}$ & $6,13 \mathrm{~b}$ & $6,13 \mathrm{~b}$ & $6,13 \mathrm{~b}$ \\
\hline \multirow[t]{4}{*}{ Abdomen } & \multirow[t]{2}{*}{ Length } & $\sigma^{\prime \prime}$ & $1,59 \mathrm{a}$ & $1,98 \mathrm{a}$ & $5,82 \mathrm{a}$ & $8,45 \mathrm{a}$ & $8,45 \mathrm{a}$ & $8,55 \mathrm{a}$ \\
\hline & & Q & $2,19 \mathrm{~b}$ & $2,28 \mathrm{~b}$ & $6,22 b$ & $8,57 \mathrm{~b}$ & $8,57 \mathrm{~b}$ & $8,72 \mathrm{~b}$ \\
\hline & \multirow[t]{2}{*}{ Width } & $\sigma^{\prime}$ & $1,51 \mathrm{a}$ & $1,64 \mathrm{a}$ & $5,63 \mathrm{a}$ & $7,95 \mathrm{a}$ & $7,95 \mathrm{a}$ & $7,97 \mathrm{a}$ \\
\hline & & Q & $1,92 \mathrm{~b}$ & $1,94 \mathrm{~b}$ & $5,78 \mathrm{~b}$ & $8,03 \mathrm{~b}$ & $8,03 \mathrm{~b}$ & $8,82 \mathrm{a}$ \\
\hline \multirow[t]{2}{*}{ Antenna } & \multirow[t]{2}{*}{ Length } & $\sigma^{\prime \prime}$ & $2,68 \mathrm{a}$ & $3,25 \mathrm{a}$ & $10,21 \mathrm{a}$ & $14,02 \mathrm{a}$ & $14,02 \mathrm{a}$ & $14,02 \mathrm{a}$ \\
\hline & & $Q$ & $2,63 \mathrm{~b}$ & $3,02 \mathrm{~b}$ & $10,65 \mathrm{~b}$ & $13,94 \mathrm{~b}$ & $13,94 \mathrm{~b}$ & $13,94 \mathrm{~b}$ \\
\hline
\end{tabular}

Data followed by different letters in each stage show significantly different $(\mathrm{P}<0,05)$.

Tabel 2. Stadium longevity average of $C$. capitulatus Fabricius on fameflower (Talinum paniculatum GERTN)

\begin{tabular}{|c|c|c|}
\hline Stadium & Sex & Average stage duration (days) \pm SD \\
\hline \multirow[t]{2}{*}{ Egg } & $\sigma$ & $4,2 \pm 0,17 \mathrm{a}$ \\
\hline & q & $6,8 \pm 0,28 \mathrm{~b}$ \\
\hline \multirow[t]{2}{*}{$1^{\text {st }}$ instar nymph } & $\sigma$ & $2,3 \pm 0,13 \mathrm{a}$ \\
\hline & Q & $4,4 \pm 0,31 \mathrm{~b}$ \\
\hline \multirow[t]{2}{*}{$2^{\text {nd }}$ instar nymph } & $\sigma$ & $2,3 \pm 0,14 \mathrm{a}$ \\
\hline & Q & $2,6 \pm 0,15 b$ \\
\hline \multirow[t]{2}{*}{$3^{\text {rd }}$ instar nymph } & $\sigma$ & $1,0 \pm 0,33 \mathrm{a}$ \\
\hline & Q & $2,3 \pm 0,18 \mathrm{a}$ \\
\hline \multirow[t]{2}{*}{$4^{\text {th }}$ instar nymph } & $\sigma^{\prime \prime}$ & $2,3 \pm 0,79 a$ \\
\hline & Q & $5,1 \pm 0,40 \mathrm{a}$ \\
\hline \multirow[t]{2}{*}{$5^{\text {th }}$ instar nymph } & $\sigma^{\prime}$ & $2,4 \pm 0,85 \mathrm{a}$ \\
\hline & Q & $6,6 \pm 0,48 b$ \\
\hline \multirow[t]{2}{*}{ Adult } & $\sigma$ & $7,0 \pm 0,55 \mathrm{a}$ \\
\hline & Q & $8,1 \pm 0,50 \mathrm{a}$ \\
\hline \multirow[t]{2}{*}{ Egg to Adult } & $\sigma^{\prime}$ & $14,8 \pm 0,30 \mathrm{a}$ \\
\hline & Q & $27,7 \pm 0,48 \mathrm{~b}$ \\
\hline
\end{tabular}

Data followed by different letters in each stage shows significantly different $(\mathrm{P}<0,05)$.

Cletus capitulatus, from the $1^{\text {st }}$ instar nymph until adult, destroys the fameflower by sucking the liquid in fruit or seed. As a result, the color of the fruit turns to black and brown like burnt, then falls off. This is a big disadvantage if the cultivation is conducted by using a seed. As reported by [9] stating that the population of
Cletus sp. (Coreidae: Hemiptera) often reach the peak during the milky seed stage, then they feed the seed and causes discoloration, wilting and the seed will be loss, as a consequence reducing yield and viability on spinach. 


\subsection{Pre-adult Development and Life Span of Cletus capitulatus}

The required time for $C$. capitulatus to complete their development from egg to adult was 14.8 \pm 0.30 days for male and $27.7 \pm 0.48$ days for female (Table 2). The adult phase (imago) is the longest phase in the life cycle of C. capitulatus, which is $7.0 \pm 0.55$ days for male and $8.1 \pm 0.50$ days for female. There was no significant difference between male and female (Table 2). In insects, female generally lives longer than male [10]. The $3^{\text {rd }}$ instar nymph has the shortest stage duration, which is $1.0 \pm 0.33$ days for male and $2.3 \pm$ 0.18 days for females

\section{CONCLUSION}

The average developmental time of $C$. capitulatus from egg to adult on fameflower was 14.8 \pm 0.30 days for male and $27.7 \pm 0.48$ for female. The female lives longer than the male, and has bigger body size compared to male. Cletus capitulatus destroys the fameflower by sucking the liquid from the fruit or seed of fameflower. The affected fruit turns to black and brown like burnt then falls off. This, eventually causes high losses. Therefore, further research is required particularly on the development of environmentally friendly control strategies of $C$. capitulatus.

\section{ACKNOWLEDGMENT}

We would like to thanks to Agricultural Research and Development Agency, The Ministry of Agriculture for providing research funding. Thank is also conveyed to those who cannot be named one by one who have helped in this study.

\section{REFERENCES}

[1] S. Wahyuni, S and E. Hadipoentyanti, Karakteristik Talinum panicultum GAERTN. Dan Talinum triangulare WILLD, Warta Tumbuhan Obat Indonesia. Vol. 5, no.4, pp. 5-6, 1999.

[2] D. Seswita, Som Jawa (Talinum paniculatum) ginseng Indonesia penyembuh berbagai penyakit, Warta Penelitian dan Pengembangan Tanaman. Vol. 16, no.2, pp. 21-23, 2010.

[3] I. Darwati, M. Rahardjo, S.M.D. Rosita, Produktivitas somjawa (Talinum paniculatum Gaertn.) pada beberapa komposisi bahan organic, Jurnal Littri. Vol. 6, no. 1, pp. 1-4, 2000.

[4] L.N. Lestario, A.E. Christian, Y. Martono, Aktivitas antioksidan daun ginseng Jawa (Talinum paniculatum Gaertn), Agritech. Vol. 29, no. 2, pp. 71-78, 2009.

[5] R.N. Kagali, E.N. Kioko, Z. Osiemo, S. Muya, C. Wachera, Insect abundance and diversity on cultivated Amaranthus spp. (Amaranthaceae) in Meru County, Kenya, American International Journal of Contemporary Research. Vol. 3, no. 7, pp. 110-116, 2013.

[6] A.B.O. Ogedegbe, A.E. Ezeh, Effect of variety and nutrient on insect pest infestation of Amaranthus spp, J. Appl. Sci. Environ. Management. Vol. 19, no. 2, pp. 251-256, 2014.

[7] I.E. Lestari, Suhartini, Triatmanto, Pengaruh pola tanaman padi (Oryza sativa L) kultivar inpari sidenuk terhadap keanekaragaman jenis hama di kelompok tani Manunggal Patran desa Madurejo. Jurnal Prodi Biologi. Vol. 6, no. 7, pp. 409-416, 2017.

[8] C.A. Yusup, Interaksi tri-trofik dan keanekaragaman serangga pada pertanaman kedelai dengan beberapa Teknik pengelolaan hama. Institute Pertanian Bogor. 2016.

[9] A. Seni, Insect pest of amaranthus and their management. International journal of environment, Agriculture and Biotechnology (IJEAB). Vol. 3, no. 3, pp. 1100-1103, 2018.

[10] C.W. Fox, L. Dublin, S.J. Pollit, Gender differences in lifespan and mortality rates in two seed beetle species, Functional ecology. Vol. 17, no. 5, pp. 619-626, 2003. 